University of Nebraska - Lincoln

DigitalCommons@University of Nebraska - Lincoln

\title{
Supplementation to Meet Metabolizable Protein Requirements of Primiparous Beef Heifers: I. Performance, Forage Intake, and Nutrient Balance
}

\author{
H. H. Patterson \\ University of Nebraska-Lincoln \\ Terry J. Klopfenstein \\ University of Nebraska-Lincoln, tklopfenstein1@unl.edu \\ Don C. Adams \\ University of Nebraska-Lincoln, dadams1@unl.edu \\ Jacqueline Musgrave \\ University of Nebraska-Lincoln, jmusgrave1@unl.edu
}

Follow this and additional works at: https://digitalcommons.unl.edu/animalscifacpub

Part of the Animal Sciences Commons

\footnotetext{
Patterson, H. H.; Klopfenstein, Terry J.; Adams, Don C.; and Musgrave, Jacqueline, "Supplementation to Meet Metabolizable Protein Requirements of Primiparous Beef Heifers: I. Performance, Forage Intake, and Nutrient Balance" (2003). Faculty Papers and Publications in Animal Science. 535.

https://digitalcommons.unl.edu/animalscifacpub/535

This Article is brought to you for free and open access by the Animal Science Department at DigitalCommons@University of Nebraska - Lincoln. It has been accepted for inclusion in Faculty Papers and Publications in Animal Science by an authorized administrator of DigitalCommons@University of Nebraska - Lincoln.
} 


\title{
Supplementation to meet metabolizable protein requirements of primiparous beef heifers: I. Performance, forage intake, and nutrient balance ${ }^{1}$
}

\author{
H. H. Patterson, T. J. Klopfenstein, D. C. Adams ${ }^{2}$, and J. A. Musgrave \\ Department of Animal Science, University of Nebraska, Lincoln 68583-0908
}

\begin{abstract}
Three experiments were conducted to evaluate the response of supplementing primiparous heifers based on the metabolizable protein (MP) system during pregnancy and lactation. In Exp. 1, 12 pregnant, March-calving heifers $(432 \pm 10 \mathrm{~kg})$ grazing Sandhills range were randomly allotted to one of two treatments: supplementation based on either the MP system (MPR) or the CP system (CPR). Supplements were fed to individual heifers from October to February and no hay was offered. Grazed forage organic matter intake (FOMI) was measured in November, January, and February. In Exp. 2, 18 heifers ( $424 \pm 8 \mathrm{~kg}$ ) were randomly allotted to one of three treatments: 1) supplementation based on the MP system with hay fed in January and February (average $2.0 \mathrm{~kg} / \mathrm{d}$; MPR/hay), 2) supplementation based on the CP system, with hay fed in January and February (CPR/hay), or 3) supplementation based on the MP system, with no hay fed (MPR/no hay). Supplements were fed from October to February, and FOMI was measured in December and February. In Exp. 3, lactating 2-yr-old cows (394 $\pm 7 \mathrm{~kg})$ maintained on meadow hay were supplemented to meet either 1) MP requirements (LMPR) or 2) degradable intake protein requirements (LDIPR). Body weight (BW) and body
\end{abstract}

condition score change, hay intake, and milk production were measured. In Exp. 1, grazed FOMI decreased ( $P$ $=0.0001$ ) from $1.9 \%$ of $\mathrm{BW}$ in November to $1.2 \%$ in February, but no differences among treatments were detected for FOMI or BW change. In Exp. 2, grazed FOMI declined $(P=0.0001)$ from $1.7 \%$ of BW in December to $1.1 \%$ in February, with no differences among treatments. Heifers on the MPR/hay and CPR/hay treatments had higher $(P=0.0018)$ total intake (grazed forage + hay intake) in February (1.7\% BW) than the MPR/no hay heifers (1.1\% BW). Heifers on the MPR/ no hay treatment had a lower weight $(P=0.02)$ and tended $(P=0.11)$ to have a lower BCS than heifers on other treatments. In Exp. 3, the LMPR cows had higher $(P=0.02)$ ADG than LDIPR cows $(0.41$ and 0.14 , respectively), but treatment did not affect milk production. Organic matter hay intake averaged $2.4 \%$ of BW. We conclude that supplementation to meet MP requirements had little benefit to heifer performance during gestation, but increased weight change during lactation. Because grazed forage intake decreased from 1.9 to $1.1 \%$ of BW with advancing gestation, supplemental energy is necessary to reduce weight and condition loss of gestating hefiers grazing dormant Sandhills range.

Key Words: Cows, Heifers, Intake, Lactation, Pregnancy, Protein

(C2003 American Society of Animal Science. All rights reserved.

J. Anim. Sci. 2003. 81:800-811

\section{Introduction}

The metabolizable protein (MP) requirement of heifers increases exponentially in the last trimester of gestation (NRC, 1996). Because the MP value of grazed winter forage is low (Lardy, 1997), a MP deficiency might exist during the winter in spring-calving heifers. The CP system does not differentiate between the re-

\footnotetext{
${ }^{1}$ Published with the approval of the director of the Univ. of Nebraska-Lincoln, Institute of Agric. and Nat. Resources, Agric. Res. Div. as Journal Ser. No. 13340.

${ }^{2}$ Correspondence: Univ. of Nebraska West Central Research and Extension Center; Rte. 4, Box 46A, North Platte 69102.

Received December 11, 2001.

Accepted October 22, 2002.
}

quirements of ruminal microbes and the MP requirements of cattle. Therefore, basing supplementation decisions on the $\mathrm{CP}$ system may result in MP deficiencies. We demonstrated that feeding supplemental undegradable uptake protein (UIP) to spring-calving heifers during the winter to meet MP requirements improved subsequent 2-yr-old pregnancy rate (Patterson et al., 2000a). We hypothesized that supplementing UIP to meet MP requirements of heifers during the winter would have positive effects on performance and nutrient balance.

Cows in late pregnancy have been shown to have lower intakes than nonpregnant cows (Jordan et al., 1973), but this phenomenon was not observed in heifers grazing tallgrass prairie (Vanzant et al., 1991). Intake of grazed forage by pregnant heifers grazing Sandhills winter range has not been reported. 
Table 1. Temperature, wind speed, and precipitation during the winters of 1997 to 1998 and 1998 to 1999 at Whitman, NE

\begin{tabular}{|c|c|c|c|c|c|c|c|c|c|c|}
\hline Item & Oct. & Nov. & Dec. & Jan. & Feb. & Oct. & Nov. & Dec. & Jan. & Feb. \\
\hline Minimal high temp., ${ }^{\circ} \mathrm{C}$ & -7.2 & -2.9 & -3.7 & -10.9 & -2.7 & 4.9 & -2.2 & -18.2 & -12.2 & -1.5 \\
\hline Maximal high temp., ${ }^{\circ} \mathrm{C}$ & 32.6 & 18.9 & 16.2 & 16.4 & 16.8 & 26.2 & 24.5 & 22.0 & 15.6 & 22.0 \\
\hline Average low temp, ${ }^{\circ} \mathrm{C}$ & 0.2 & -6.1 & -7.4 & -9.4 & -3.8 & 0.1 & -2.9 & -10.7 & -10.0 & -6.0 \\
\hline Minimal low temp., ${ }^{\circ} \mathrm{C}$ & -17.5 & -16.4 & -15.9 & -22.8 & -7.8 & -4.4 & -10.2 & -30.2 & -21.9 & -11.6 \\
\hline Precipitation, $\mathrm{cm}$ & 11.3 & 0.6 & 0.9 & 0.6 & 1.7 & 9.3 & 6.6 & 0.2 & 0.3 & 1.8 \\
\hline
\end{tabular}

Lactating 2-yr-old cows have a high requirement for MP relative to nonlactating cows (NRC, 1996). Supplementing UIP to young, lactating cows improved BW gain and the percentage of cows that bred early in the breeding season (Wiley et al., 1991). We hypothesized that meeting NRC (1996) MP requirements for lactating 2-yr-old cows would positively affect production traits.

The objectives of this study were to: 1) determine BW and BCS change and forage intake of pregnant heifers grazing winter range when supplemented based on the MP system (NRC, 1996) or the CP system; 2) determine the effects of winter hay feeding on heifer performance; and 3) determine the effects of supplementing to meet NRC (1996) MP or degradable intake protein requirements of 2-yr-old lactating cows on performance, intake, and milk production.

\section{Materials and Methods}

\section{Experiment 1}

This experiment was conducted at the University of Nebraska Gudmundsen Sandhills Laboratory (GSL) near Whitman, $\mathrm{NE}$ (elevation $1,073 \mathrm{~m}$, lat $42^{\circ} 05^{\prime} \mathrm{N}$, long $101^{\circ} 26^{\prime} \mathrm{W}$ ). The average annual precipitation from 1997 to 1999 was $59 \mathrm{~cm}$. Table 1 shows monthly high and low temperatures, average wind speed, and precipitation for the months in which the experiment was conducted. Twelve pregnant, primiparous heifers (average calving date March 1) grazing native range were stratified by BW $(432 \pm 10 \mathrm{~kg})$ and BCS $(6.4 \pm 0.2)$ on October 2, 1997 and randomly allotted to one of two supplemental treatments (six heifers/treatment). Treatments were two systems of supplementation designed to: 1) meet the MP requirement of the heifers through the winter (MPR), or 2) meet the CP requirement of the heifers (CPR). Feather meal was used for the UIP source in the MPR supplement (Table 2), which contained 53\% CP and 28\% UIP (DM basis). The CPR supplement contained 51\% CP and 14\% UIP. Supplements were individually fed three times weekly starting October 13. The CPR supplement was fed at the rate of $409 \mathrm{~g} / \mathrm{d}(\mathrm{DM})$ throughout the trial, supplying $57 \mathrm{~g}$ of
UIP/d. The MPR supplement feeding rate was increased gradually from $310 \mathrm{~g} / \mathrm{d}$ in October to $496 \mathrm{~g} / \mathrm{d}$ in February to balance MP requirements, supplying $87 \mathrm{~g}$ of UIP/d in October, $127 \mathrm{~g}$ UIP/d in November, December, and January, and $140 \mathrm{~g}$ UIP/d in February. Heifers were not fed hay during the experiment. Beginning October 22 , BW were measured twice weekly and BCS once monthly. Body weights were taken with no prior shrink at approximately 1300 each weigh day, and BCS were assigned by two trained technicians based on palpation of the ribs and vertebra $(1=$ thin to $9=$ obese; as described by Richards et al., 1986). The heifers were weighed and assigned a final BCS on February 13, 1998.

Heifers grazed in one 33-ha pasture throughout the experiment at a stocking rate of 1.7 animal unit months (AUM) per hectare. The pasture was located on a sands range site in good to excellent condition, which was

Table 2. Composition of supplements (DM basis) fed to heifers grazing Nebraska Sandhills range from October to February of 1997 to 1998 (Exp. 1) and 1998 to 1999 (Exp. 2)

\begin{tabular}{lcc}
\hline \hline Item & $\mathrm{MPR}^{\mathrm{b}}$ & $\mathrm{CPR}^{\mathrm{c}}$ \\
\hline Ingredients & - & \\
Cottonseed meal & 40.2 & 58.8 \\
Feather meal & - & - \\
Soybean meal & 30.2 & 17.8 \\
Sunflower meal & 26.2 & 13.7 \\
Wheat middlings & - & - \\
Distillers grains & 2.1 & 3.4 \\
Cane molasses & - & 2.1 \\
Urea & 1.1 & 2.8 \\
Salt & 0.2 & 1.1 \\
Vitamin A premix & - & 0.2 \\
Limestone & & 0.1 \\
Nutrients & 91.4 & 89.6 \\
DM, \% & 52.9 & 51.7 \\
CP & 28.0 & 14.0 \\
UIP & 0.8 & 0.3 \\
Ca & 0.8 & 1.0 \\
P & & \\
\hline
\end{tabular}

${ }^{\text {aS }}$ Spplements fed three times weekly.

${ }^{b}$ Formulated to meet metabolizable protein requirement.

${ }^{\mathrm{c}}$ Formulated to meet $\mathrm{CP}$ requirement.

${ }^{\mathrm{d}}$ Undegradable intake protein. 
dominated by little bluestem (Schizachyrium scoparium [Michx.] Nash), prairie sandreed (Calamovilfa longifolia [Hook.] Scribn.), sand bluestem (Andropogon gerardii var. paucipilus [Nash] Fern.), and switchgrass (Panicum virgatum L). Estimates of standing herbage taken from a similar, adjacent pasture in October were used to calculate cumulative grazing pressure (total AUM per metric ton of DM forage initially available), which was approximately $0.65 \mathrm{AUM} / \mathrm{t}$.

Beginning November 10, 1997, January 5, 1998, and February 9, 1998, fecal output was determined in 6-d fecal collection periods so that forage intake could be determined. All 12 heifers and four additional steers (November intake only) were orally dosed with a Captec Chrome for Cattle (Captec Pty. Ltd., Australia, distributed internationally by Nufarm Ltd., Otahunu, Auckland 6, New Zealand) intraruminal $\mathrm{Cr}$ sesquioxide time-release capsule (mean release rate of $1.49 \mathrm{~g} / \mathrm{d}$ ) $7 \mathrm{~d}$ before initiation of fecal collection. Rectal fecal samples were collected from all cattle at 0730 each morning of the 6 -d collection periods. Samples were immediately frozen and stored until chemical analysis. On the first day of fecal collection in November, the four steers (383 $\mathrm{kg}$, siblings to heifers) were fitted with total fecal collection bags. Bags were emptied at 0730 and 1700 each day for five 24-h collection periods, and feces in the bags were weighed, mixed, and subsampled (approximately $500 \mathrm{~g}$ ). Subsamples were immediately placed in a $60^{\circ} \mathrm{C}$ oven for DM determination. Total fecal collections were used to correct for daily Cr release from capsules as described by Adams et al. (1991). The correction obtained from total fecal collection in November was used to correct fecal output estimates at the other fecal collection periods (Hollingsworth-Jenkins et al., 1996). The steers used for total fecal collection received no supplement. Rectal fecal samples taken from heifers on the day of oral capsule administration were used to adjust for baseline $\mathrm{Cr}$ concentration in feces. Fecal output was determined for each animal from the mean $\mathrm{Cr}$ concentration in fecal composites (composited across days for each animal during each fecal collection period) by the following equation: $\mathrm{OM}$ fecal ouput $(\mathrm{kg})=\mathrm{Cr}$ payout per day (mg)/concentration of $\mathrm{Cr}$ in fecal composites $(\mathrm{mg} / \mathrm{kg})$. Forage OM intake (FOMI) was calculated as described by Kartchner (1981): FOMI = (total fecal OM daily excretion - estimated fecal OM from supplement)/ (diet in vitro $\mathrm{OM}$ indigestibility).

Extrusa samples were collected from three esophageally fistulated cows at two times during each fecal collection periods in November, January, and February (n $=6$ diets/collection period). The cow's ages ranged from 2 to $10 \mathrm{yr}$ and BW from $515 \mathrm{~kg}$ for young cows to 621 $\mathrm{kg}$ for aged cows. Cows were crossbreeds including Red Angus, Hereford, and Simmental. Extrusa samples were also collected on October 8 and December $6(\mathrm{n}=$ 3 diets/collection). Extrusa samples were collected by allowing cows to graze without the esophageal plug for 20 to $30 \mathrm{~min}$. Extrusa was collected in screen-bottom bags and immediately frozen.
Extrusa and rectal fecal samples were freeze-dried and ground to pass a 1-mm screen in a Wiley mill. Fecal bag subsamples (dried at $60^{\circ} \mathrm{C}$ ) were ground to pass a 1-mm screen. Rectal fecal composites, extrusa samples, and fecal bag subsamples were analyzed for DM and OM by AOAC (1990) methods. Chromium concentration was determined in rectal fecal composites by atomic absorption spectrophotometry using an air-plus-acetylene flame (Williams et al., 1962). Crude protein content of extrusa samples was determined by AOAC (1990) methods. In vitro organic matter disappearance (IVOMD) and in vitro dry matter disappearance were determined on extrusa samples using a modified Tilley and Terry (1963) procedure with the addition of $1 \mathrm{~g}$ of urea to the buffer (Weiss, 1994). Forage UIP (and thus degradable intake protein; DIP) was determined as described by Klopfenstein et al. (2000). In brief, samples were incubated in situ for $48 \mathrm{~h}$, and NDF extraction was performed on the in situ bags (Mass et al., 1999). Forage UIP was determined by the amount of neutral detergent insoluble $\mathrm{N}$ remaining after $48 \mathrm{~h}$. A 48-h incubation period was chosen to represent the estimated mean retention time of forage particles in the rumen (Lamb, 1996).

Heifer BW data were averaged within week. Body weight and BCS data were analyzed as repeated measures (Littell et al., 1996) using the Mixed procedure of SAS (SAS Inst., Inc., Cary, NC). Because data were not equally spaced, the $\mathrm{SP}(\mathrm{POW})$ procedure was used to fit the time-series type covariance structure. Quadratic equations were fitted for each response variable over time, and time linear $\times$ treatment and time quadratic $\times$ treatment interactions were determined by the presence of significant coefficients for one treatment but not the other (Littell et al., 1996). The effects of treatment and period ( $2 \times 3$ factorial arrangement) on fecal output and FOMI were determined by ANOVA in the GLM procedure of SAS.

Intake and nutrient data were used in the NRC (1996) model to determine nutrient balance of the heifers at the time of intake estimation. Data were modeled assuming thermoneutral conditions and a 9.5\% microbial efficiency. Forage intake, CP, and UIP, which were calculated on an OM basis, were adjusted to a DM basis by assuming $10 \%$ ash. In vitro DM diasppearance was used to estimate forage TDN.

\section{Experiment 2}

On October 21, 1998, 18 pregnant heifers (average calving date was March 23) at GSL were stratified by BW $(424 \pm 8 \mathrm{~kg})$ and BCS $(6.1 \pm 0.2)$ and randomly allotted to one of three treatments. Supplements were the same as those described in Exp. 1 (Table 2), and treatments were three winter management systems: 1 ) supplementation to meet MP requirements with hay fed in January and February (MPR/hay), 2) supplementation to meet $\mathrm{CP}$ requirements with hay fed in January and February (CPR/hay), and 3) supplemen- 
tation to meet MP requirement with no hay fed in January and February (MPR/no hay). Supplements were fed as described in Exp. 1. Heifers were managed on the same pasture described for Exp. 1, at a stocking rate of $2.6 \mathrm{AUM} / \mathrm{ha}$ and an approximate cumulative grazing pressure of $0.99 \mathrm{AUM} / \mathrm{t}$. Monthly temperature, wind, and precipitation data are shown in Table 1. Hay was individually fed three times weekly at the rate of $1.4 \mathrm{~kg} / \mathrm{d}$ (OM basis) beginning January 4, 1999. The amount was gradually increased to $1.8 \mathrm{~kg} / \mathrm{d}$ by February 1 and $2.3 \mathrm{~kg} / \mathrm{d}$ by mid-February. The hay was harvested from a subirrigated meadow in late June and contained 8.5\% CP, 78\% NDF (OM basis), and 57\% IVOMD. Heifers were weighed weekly and assigned a BCS monthly by two trained technicians (except December). The experiment ended on February 21, 1999.

Fecal output was determined in two, 6-d fecal collection periods beginning December 15, 1998 and February 18,1999 . Cattle were orally administered a time-release Cr capsule, and fecal measurements taken as previously described. Four steers were used to correct $\mathrm{Cr}$ payout from time-release capsules by total fecal collection in December and February. The steers were siblings of the heifers and weighed $419 \mathrm{~kg}$. The December total fecal collection was used to adjust predicted fecal output for all heifers in December and for the MPR/No Hay heifers in February. The four steers used for total fecal collection in February were fed the previously described meadow hay ( $2 \mathrm{wk}$ before fecal sampling) in similar quantities as the MPR/hay and CPR/hay heifers. The February total fecal collection was used to adjust fecal output measurements for the MPR/hay and CPR/hay heifers in February. Extrusa samples were collected using esophageally fistulated cows (same cows as Exp. 1) on October $19(\mathrm{n}=3)$, December 16 and $18(\mathrm{n}=6)$, January 16 $(\mathrm{n}=2)$, and February 19 and $20(\mathrm{n}=4)$. In vitro OM disappearance of extrusa samples collected during fecal collection periods was used to calculate forage intake from fecal output measurements. In February, grazed FOMI of heifers on the MPR/hay and CPR/hay treatments was calculated by: grazed FOMI $=($ total OM fecal excretion - estimated fecal OM from hay - estimated fecal OM from supplement)/(1 - diet IVOMD). Differences among treatments in fecal output, grazed FOMI, or grazed FOMI + hay intake were determined using $a$ priori contrasts in the GLM procedure of SAS (MPR/hay vs CPR/hay and hay feeding vs no hay feeding). All other analyses were as previously described.

\section{Experiment 3}

The experiment was conducted at GSL in spring 1999, using the 18 2-yr-old cows described in Exp. 2 (average calving date March 23). Cows were maintained in a large drylot and allowed ad libitum access to late-June harvested meadow hay (9.5\% $\mathrm{CP}, 1.8 \% \mathrm{UIP}, 80 \% \mathrm{NDF}$ (OM basis), and 54\% IVOMD). On April 5, 1999 cows that were at least $7 \mathrm{~d}$ postpartum $(\mathrm{n}=13)$ were blocked by previous winter treatment, stratified by BW and BCS,
Table 3. Composition of supplements fed to lactating 2-yr-old cows (Exp. 3) consuming meadow hay (DM basis) ${ }^{a}$

\begin{tabular}{lcc}
\hline \hline Item & $\mathrm{LMPR}^{\mathrm{b}}$ & $\mathrm{LDIPR}^{\mathrm{c}}$ \\
\hline Ingredients & & \\
Soybean meal & 55.0 & - \\
Feather meal & 38.4 & - \\
Soybean hulls & 6.6 & 93.1 \\
Urea & - & 6.9 \\
Nutrients & & \\
DM, \% & 91.2 & 90.5 \\
CP & 61.1 & 31.9 \\
UIP & 31.4 & 2.2 \\
Ca & 0.31 & 0.41 \\
$\mathrm{P}$ & 0.69 & 0.17 \\
\hline
\end{tabular}

aSupplements fed thee times weekly from 15 to $64 \mathrm{~d}$ after parturition. Meadow hay was $9.5 \%$ CP, $80 \%$ NDF (OM basis).

${ }^{\mathrm{b}}$ Formulated to meet metabolizable protein requirement.

${ }^{\mathrm{c}}$ Formulated to meet the degradable intake protein requirement.

${ }^{\mathrm{d}}$ Undegradable intake protein.

and randomly assigned to one of two supplement treatments. Treatments were 1) supplementation to meet MP requirements (LMPR), and 2) supplementation to meet DIP requirements (LDIPR). Cows and their calves were weighed both on April 5 and 6 at 0800 without deprivation from food or water, and a BCS (Richards et al., 1986) was assigned by two trained technicians on each day. At 7-d intervals, cows that were not allotted to treatments on April 5 but were at least $7 \mathrm{~d}$ postpartum, were assigned alternately to one of the two supplemental treatments. Cows and their calves were weighed, and cows were assigned a BCS on two consecutive days at 0800 when allotted to treatments. The five cows that were not allotted to treatments on April 5 eventually calved, with one additional cow added on April 12 and four cows added on April 19. Cows and calves were weighed off-test (without deprivation from feed or water), and cows were assigned a BCS at 0800 on May 27 and 28, 1999.

Both supplements were formulated to meet DIP requirements, and the LMPR had additional UIP to balance MP requirements (Table 3). Requirements were generated using the NRC (1996) model assuming a peak milk production of $5.4 \mathrm{~kg}$, forage DM intake of $2.5 \%$ of BW (DM basis), and diet microbial yield of $10.5 \%$ of TDN. The LMPR supplement was $61 \% \mathrm{CP}$ and $31 \%$ UIP (DM basis) and the LDIPR supplement was $32 \% \mathrm{CP}$ and $2 \%$ UIP. The LMPR was fed at the rate of $545 \mathrm{~g} / \mathrm{d}$ (169 $\mathrm{g}$ of UIP/d), and the LDIPR supplement was fed at the rate of $590 \mathrm{~g} / \mathrm{d}(12 \mathrm{~g}$ of UIP/d). Supplements were pelleted and fed three times weekly from April 7 to May 24, 1999. Any refused supplement was weighed and the amount recorded.

Twelve-hour milk production was determined by the weigh-suckle-weigh method on April 21 and May 18. On the day before measurements, the calves were removed at 1300 and were kept separate from dams until 1900, when they were allowed to suckle, and again removed. 
Table 4. Means and standard deviations of nutrient composition (OM basis) of extrusa samples collected by esophageally fistulated cows grazing winter range in the Nebraska Sandhills in 1997 to 1998 (Exp. 1) and 1998 to 1999 (Exp. 2) ${ }^{\mathrm{a}}$

\begin{tabular}{|c|c|c|c|c|c|c|c|c|c|}
\hline Nutrient & \multicolumn{5}{|c|}{1997 to 1998} & \multicolumn{4}{|c|}{1998 to 1999} \\
\hline $\mathrm{CP}$ & $9.1 \pm 0.9$ & $5.8 \pm 0.5$ & $7.4 \pm 1.4$ & $5.8 \pm 0.5$ & $5.7 \pm 1.6$ & $8.4 \pm 1.9$ & $6.6 \pm 1.2$ & $5.4 \pm 0.3$ & $6.2 \pm 1.1$ \\
\hline $\mathrm{UIP}^{\mathrm{b}}$ & 1.1 & 1.3 & 1.5 & 1.2 & 1.5 & 1.6 & 1.6 & 1.4 & 1.8 \\
\hline $\mathrm{DIP}, \% \mathrm{CP}^{\mathrm{c}}$ & 87.9 & 78.5 & 79.7 & 78.8 & 73.3 & 81.4 & 76.1 & 73.6 & 68.6 \\
\hline IVOMD $^{\mathrm{d}}$ & $52.7 \pm 1.5$ & $53.4 \pm 2.3$ & $51.4 \pm 2.2$ & $50.8 \pm 2.3$ & $50.5 \pm 3.2$ & $53.1 \pm 0.6$ & $52.9 \pm 2.7$ & $48.3 \pm 3.4$ & $48.3 \pm 2.0$ \\
\hline
\end{tabular}

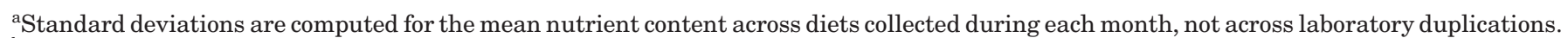

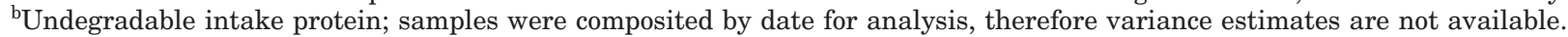

${ }^{\mathrm{c}}$ Degradable intake protein.

${ }^{\mathrm{d} I n}$ vitro organic matter disappearance.

On the measurement day, calves were weighed at 0700, allowed to suckle, and then weighed again. Twenty-fourhour milk production was estimated by doubling 12 -h milk production.

Fecal output was determined during one 6-d collection period beginning May 3 as described for Exp. 1. Adjustments were made for daily $\mathrm{Cr}$ payout as previously described using four steers. Steers were penned with heifers and allowed access to the same hay from $1 \mathrm{wk}$ before Cr capsule administration through the collection period. Steers were not supplemented (Hollingsworth-Jenkins et al., 1996). Fecal analysis and intake calculations were as previously described.

Beginning April 12, cows were bled once weekly via jugular venipuncture. Plasma was harvested by centrifugation and stored in plastic screw-cap vials at $-20^{\circ} \mathrm{C}$. Plasma progesterone was determined by RIA (Coat-ACount assay kit; Diagnostic Product Corp., Los Angeles, CA) by the methods of Melvin et al. (1999). Animals were considered to be exhibiting normal estrous activity when plasma progesterone was greater than $1 \mathrm{ng} / \mathrm{mL}$.

Data were analyzed in an unbalanced block design using the GLM procedure of SAS. The design was unbalanced because an equal number of cows from previous winter treatment (block) was not represented in each treatment of this study. Calving date was tested as a covariate for all variables. Calving date was only significant as a covariate for cow ADG, calf initial weight, and calf final weight.

The University Animal Care and Use Committee approved procedures for all three experiments, including establishment of fistulas in cows.

\section{Results and Discussion}

\section{Experiments 1 and 2}

Crude protein content of esophageal extrusa samples was relatively consistent across experiments, ranging from 9.1 to 5.7\% in Exp. 1 and 8.4 to 5.4\% in Exp. 2 (Table 4). Forage UIP ranged from 1.1 to $1.8 \%$ of OM across experiments. Both the level and range of winter Sandhills forage UIP was similar to that reported by Lardy (1997) using the procedures of Mass et al. (1999).
Most of the variability in winter Sandhills forage CP content was associated with the DIP fraction. Extrusa sample IVOMD declined in January and February in both experiments compared to October and December diets, but the decline was greater in Exp. 2 (0.9 and 4.5 percentage unit decline from December to February in Exp. 1 and 2, respectively). The higher stocking rate in the second experiment (1.7 vs 2.6 AUM/ha for Exp. 1 and 2, respectively) could have potentially caused the reduction in diet digestibility. Vavra et al. (1973) showed that increased stocking intensities of yearling cattle during the summer reduced diet digestibility in some situations, but found very little effect of stocking intensity on CP. In the Nebraska Sandhills, Yates et al. (1982) found that $\mathrm{CP}$ content of continuously grazed pastures declined over the winter, but increased cumulative grazing pressure had no effect on diet digestibility. Downs (1997) showed that IVOMD declined linearly with increased winter stocking rate. Patterson et al. (2000b) found that the CP and IVOMD of fall Nebraska Sandhills range declined with increased grazing pressure in 1997, but not in 1998. The cause of lower diet IVOMD in Exp. 2 is not certain, but it is likely due to increased grazing pressure. Both the low IVOMD (energy) and UIP value of Sandhills winter range caused the forage to have a low MP value.

Extrusa sample IVOMD used to calculate FOMI in Exp. 1 was $53.4 \%$ in January, 51.4\% in December, and $50.5 \%$ in February. Due to heifers regurgitating the time-release capsules in Exp. 1, there were only five heifers included in the intake analysis for the CPR treatment in November, both treatments in January, and the MPR treatment in February. Organic matter fecal output and FOMI (kg/d and percentage of BW) did not differ $(P=0.25)$ between treatments, and no treatment $\times$ intake period interactions $(P=0.63)$ were detected (Table 5). Heifers on the CPR treatment had a lower BW during intake measurements than the MPR treatment $(P=0.03)$, but this did not affect forage consumption. Fecal output and FOMI declined from November to January $(P=0.01)$ and tended to decline from January to February $(P=0.15)$. Heifer FOMI declined from 8.5 $\mathrm{kg} / \mathrm{d}(1.9 \%$ of BW) in November to $5.2 \mathrm{~kg}(1.2 \%$ of BW) in February. 
Table 5. Fecal OM output from grazed forage (FO), grazed OM forage intake (FOMI), and BW at the time of intake measurement during three intake periods in 1997 to 1998

(Exp. 1) for heifers grazing winter Sandhills range and supplemented to meet metabolizable protein requirements (MPR) or CP requirements $(\mathrm{CPR})^{\mathrm{a}}$

\begin{tabular}{|c|c|c|c|c|c|c|}
\hline \multirow[b]{2}{*}{ Item } & \multicolumn{2}{|c|}{ November 10 to 15,1997} & \multicolumn{2}{|c|}{ January 5 to 10,1998} & \multicolumn{2}{|c|}{ February 9 to 13,1998} \\
\hline & $\mathrm{MPR}^{\mathrm{b}}$ & $\mathrm{CPR}^{\mathrm{c}}$ & $\mathrm{MPR}^{\mathrm{c}}$ & $\mathrm{CPR}^{\mathrm{c}}$ & $\mathrm{MPR}^{\mathrm{c}}$ & $\mathrm{CPR}^{\mathrm{b}}$ \\
\hline $\mathrm{BW}, \mathrm{kg}^{\mathrm{d}}$ & $450 \pm 7$ & $437 \pm 8$ & $441 \pm 8$ & $434 \pm 8$ & $440 \pm 8$ & $420 \pm 7$ \\
\hline $\mathrm{FO}, \mathrm{kg}^{\mathrm{e}}$ & $4.2 \pm 0.3$ & $3.6 \pm 0.3$ & $3.1 \pm 0.3$ & $3.0 \pm 0.3$ & $2.6 \pm 0.3$ & $2.5 \pm 0.3$ \\
\hline $\mathrm{FO}, \% \mathrm{BW}^{\mathrm{e}}$ & $0.94 \pm 0.06$ & $0.83 \pm 0.07$ & $0.71 \pm 0.07$ & $0.68 \pm 0.07$ & $0.60 \pm 0.07$ & $0.61 \pm 0.07$ \\
\hline FOMI, kgf & $9.0 \pm 0.6$ & $7.8 \pm 0.6$ & $6.3 \pm 0.6$ & $6.0 \pm 0.6$ & $5.3 \pm 0.6$ & $5.1 \pm 0.6$ \\
\hline FOMI, \% BW & $2.00 \pm 0.12$ & $1.79 \pm 0.13$ & $1.44 \pm 0.13$ & $1.39 \pm 0.13$ & $1.21 \pm 0.13$ & $1.23 \pm 0.12$ \\
\hline
\end{tabular}

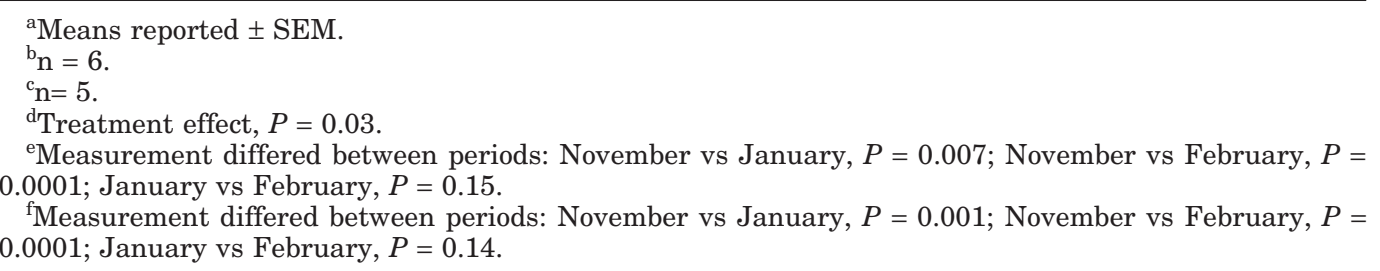

In Exp. 2, IVOMD values used to calculate FOMI were $52.9 \%$ in December and $48.3 \%$ in February. Due to heifers regurgitating time-release capsules, only 5 heifers were included in the intake analysis for both hay-fed treatments in February. Hay-fed heifers were heavier $(P=0.0005)$ during intake measurements than non-hay fed heifers (Table 6). Heifers supplemented with hay had lower fecal output from grazed forage and grazed FOMI $(P=0.004)$ than non-hay fed heifers when intake was expressed as a percentage of BW. The lack of treatment $\times$ intake period interactions $(P=0.73)$ for grazed FOMI or FO indicates that hay supplementation did not cause the reduced intake because hay was only supplemented during the February intake measurement. The difference in intake as a percentage of $\mathrm{BW}$ was possibly due to lower BW in the MPR/no hay treat- ment. Because all cattle were of similar frame size, differences in BW between treatments were likely due to body condition in February (Figure 1). It is not clear why the treatment where no hay was fed resulted in a lower BW before hay feeding began than the hay-fed treatments. Consistent with these results, Adams et al. (1987) showed that body condition of cows had no effect on amount of forage consumed, but thin cows consumed more as a percentage of BW. Organic matter fecal output from grazed forage and grazed FOMI declined from December to February $(P=0.0001)$. The decline in grazed FOMI from 1.7 to $1.1 \%$ of BW across measurement dates was similar to that noted in Exp. 1. Due to hay supplementation in February, there was a treatment $\times$ intake period interaction $(P=0.002)$ for total FOMI (hay plus grazed forage) and fecal output from

Table 6. Fecal OM output from grazed forage (FO), grazed OM forage intake (FOMI), and BW at the time of intake measurement during two intake periods in 1998 to 1999 (Exp. 2) for heifers grazing winter Sandhills range and supplemented to meet metabolizable protein requirements or $\mathrm{CP}$ requirements and fed hay in January or February (MPR/hay and CPR/hay respectively) or supplemented to meet metabolizable protein requirements and not fed hay (MPR/no hay) ${ }^{\mathrm{a}}$

\begin{tabular}{|c|c|c|c|c|c|c|}
\hline Item & \multicolumn{3}{|c|}{ December 15 to 20,1998} & \multicolumn{3}{|c|}{ February 18 to 23,1999} \\
\hline Weight, $\mathrm{kg}^{\mathrm{d}}$ & $401 \pm 9$ & $410 \pm 9$ & $386 \pm 9$ & $414 \pm 8$ & $417 \pm 8$ & $373 \pm 9$ \\
\hline $\mathrm{FO}, \% \mathrm{BW}^{\mathrm{ef}}$ & $0.71 \pm 0.05$ & $0.74 \pm 0.05$ & $0.89 \pm 0.05$ & $0.51 \pm 0.05$ & $0.56 \pm 0.05$ & $0.65 \pm 0.05$ \\
\hline FOMI, $\mathrm{kg}^{\mathrm{e}}$ & $6.0 \pm 0.4$ & $6.5 \pm 0.4$ & $7.2 \pm 0.4$ & $4.1 \pm 0.4$ & $4.5 \pm 0.4$ & $4.7 \pm 0.4$ \\
\hline FOMI, \% BW ${ }^{e f}$ & $1.50 \pm 0.10$ & $1.59 \pm 0.10$ & $1.88 \pm 0.10$ & $0.99 \pm 0.09$ & $1.09 \pm 0.09$ & $1.26 \pm 0.10$ \\
\hline
\end{tabular}

${ }^{\mathrm{a}}$ Means reported $\pm \mathrm{SEM}$.

${ }^{\mathrm{b}} \mathrm{n}=6$.

${ }^{c} \mathrm{n}=5$.

${ }^{\mathrm{d} S i g n i f i c a n t}$ contrast $(P=0.0005)$ : no hay feeding versus hay feeding.

${ }^{\mathrm{e}}$ Measurements differed $(P=0.0001)$ between December and February.

fignificant $(P=0.004)$ contrast: no hay feeding vs hay feeding.

gTreatment $\times$ intake period interaction, $P=0.002$.

hIn February, $(P=0.002)$ contrasts: no hay feeding vs hay feeding. 


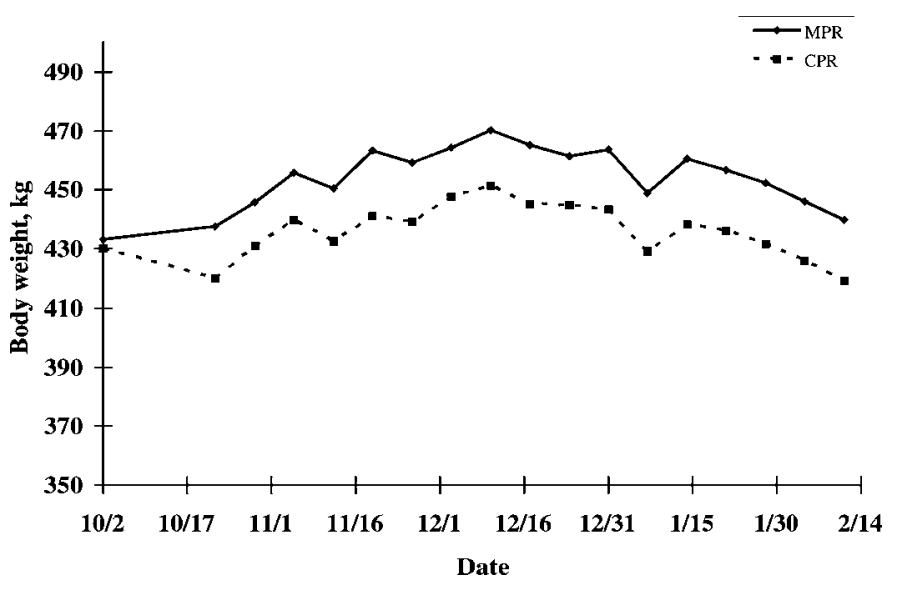

Figure 1. Body weight of heifers grazing native winter range over the winter of 1997 to 1998 (Exp. 1) when supplemented to meet metabolizable protein requirements (MPR) or $\mathrm{CP}$ requirements (CPR).

total diet. Total intake and fecal output from total diet were greater $(P=0.002)$ in February for hay-supplemented vs non-hay-supplemented heifers (both in kilograms per day and percentage of BW). Supplementing hay in February returned total forage intake to values similar to that measured in December when no hay supplementation occurred.

The degree of decline in grazed FOMI across intake periods was greater than expected. Cold ambient temperatures can cause reductions in grazed forage intake (Adams and Short, 1988) and diet digestibility (Christopherson, 1976, Kartchner, 1981). Likewise, cold stress has been demonstrated to have a larger effect on grazing time of young cows than of old cows (Adams et al., 1986). In general, average low ambient temperatures declined from October to January, but were elevated somewhat during February (Table 1). In Exp. 1, average low ambient temperatures measured $2 \mathrm{~d}$ before and during fecal collection periods were $-10.6,-13.2$, and $-4.1^{\circ} \mathrm{C}$ for November, January and February periods, respectively. In Exp. 2, average low ambient temperatures were -8.8 and $-6.7^{\circ} \mathrm{C}$ for December and February collection periods, respectively. Thus, cold ambient temperature does not likely explain the reduction in February intake during either experiment.

Increased grazing pressure and/or reduced forage allowance can cause a reduction in grazed forage intake (Allison, 1985). Pinchak et al. (1990) showed that intake was reduced during the winter when standing crop reached $600 \mathrm{~kg} / \mathrm{ha}$, with no change in diet digestibility. Although standing crop estimates were not measured directly in the present study, they would not be expected to drop below $1,200 \mathrm{~kg} / \mathrm{h}$ a at any time during the study. This is especially true during Exp. 1, when grazing pressure was 0.65 AUM/t. Patterson (2000) reported that utilization of standing forage did not increase when dormant season stocking rate was increased from 2.0 to $3.0 \mathrm{AUM} / \mathrm{ha}$, indicating that forage intake was mark- edly reduced. Low forage allowance and/or low forage digestibility may have caused a reduction in intake during February of Exp. 2. Allison et al. (1981) showed, however, that intake was not reduced at forage allowances as low $10 \mathrm{~kg} /$ animal unit day. Handl and Rittenhouse (1972) found that herbage intake was not affected with standing herbage crops as low as $175 \mathrm{~kg} / \mathrm{ha}$. These range sites were somewhat different than the Sandhills where our research was conducted, however.

Another potential cause for reduced forage intake in gestating heifers is a reduction in rumen volume due to compression of the rumen by fetus and fluids. Forbes (1969) showed a negative relationship between volume of ruminal contents and volume of incompressible abdominal contents (uterus + fat + empty intestines) in ewes. Ruminal fill can limit intake of low-quality diets (Mertens, 1994). This phenomenon has been demonstrated in twin-bearing sheep (Forbes, 1970; Ramsey et al., 1998). Jordon et al. (1973) showed that pregnant cows fed hay had $12 \%$ lower intakes 2 wk before calving than nonpregnant cows, and cows fed silage had lower intakes 8 wk before calving. Stanley et al. (1993) fed pregnant cows chopped alfalfa ( $16 \% \mathrm{CP}, 51 \% \mathrm{NDF})$ and found that DMI and indigestible ADF passage increased up to calving. Vanzant et al. (1991) showed that pregnant primiparous heifers grazing tallgrass prairie and supplemented with alfalfa pellets had higher DMI than nonpregnant heifers at 2 mo before calving and similar intakes within $2 \mathrm{wk}$ of calving. Passage of indigestible fiber was greater for pregnant than nonpregnant heifers. Digestibility estimates in the work of Vanzant et al. (1991) ranged from 55 to $60 \%$ of DM.

Rate of passage seems to increase in pregnant cattle, perhaps in an attempt to match intake with nutrient requirements. Increased passage could be caused by increased rumination time during pregnancy (Forbes, 1970) or by neural or hormonal regulation (Faichney and White, 1988). The diets in the studies of Stanley et al. (1993) and Vanzant et al. (1991) were higher in digestibility than those recorded in the present study. Rate of passage may not be sufficiently increased to compensate for reduced ruminal volume when lowquality winter range is consumed. Elevated estrogen concentrations before calving have been associated with intake reductions (Grummer et al., 1995), but this phenomenon would be more likely to exist just before parturition. The latest intake experiments described in this study were conducted approximately $28 \mathrm{~d}$ before calving. It cannot be determined from these data whether pregnancy caused a reduction in grazed forage intake. Indeed, the heifers were able to consume supplemental hay without further reduction in grazed FOMI.

Body weight measurements across time for each of the two treatments in Exp. 1 are shown in Figure 1. Heifer BW varied over time $(P=0.0001)$, but there was no overall effect of treatment $(P=0.17)$ on heifer BW (mean weights of 454 and $436 \mathrm{~kg}$ [SEM $=8.8 \mathrm{~kg}$ ] for MPR and CPR, respectively). There was a tendency ( $P$ $=0.11$ ) for a treatment $\times$ time interaction for heifer 


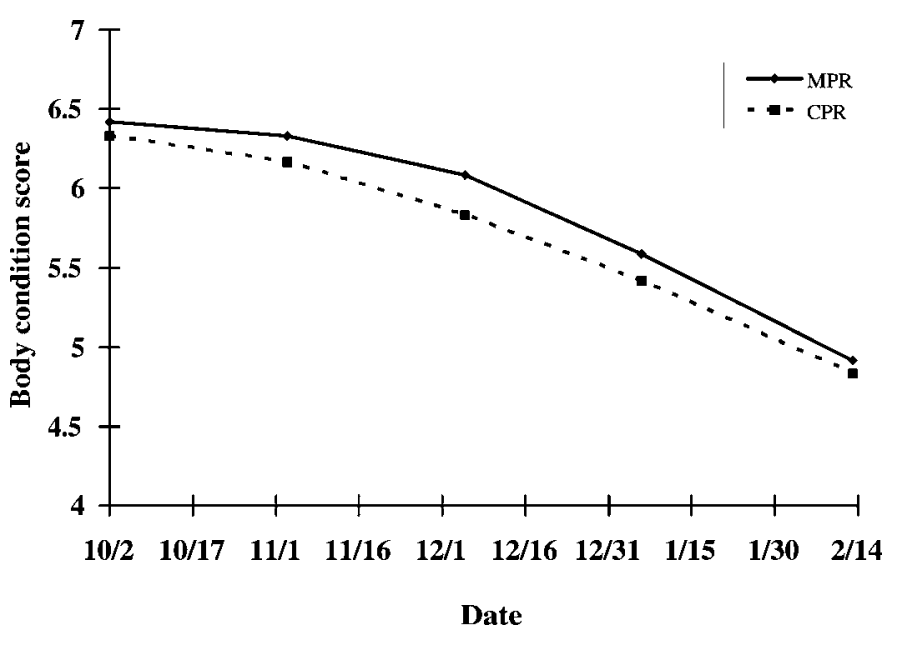

Figure 2. Body condition score ( 1 to 9 scale; $1=$ emaciated, $9=$ obese) of heifers grazing native range over the winter of 1997 to 1998 (Exp. 1) when supplemented to meet metabolizable protein (MPR) or $\mathrm{CP}$ requirements (CPR).

BW, as MPR heifers gained more BW from October to December than CPR heifers. Both groups appeared (Figure 1) to lose BW from December through February, as energy intake likely became limiting. Quadratic equations fit ( $P=0.0001)$ heifer BW change over time, but no time quadratic $\times$ treatment interactions were detected $(P=0.30)$. Heifer BCS (Figure 2$)$ varied over time $(P=0.0001)$, but there was no overall effect $(P=$ 0.31 ) of treatment on BCS (mean BCS 5.9 and 5.7 [SEM $=0.1]$ for MPR and CPR, respectively). Quadratic equations fit $(P=0.006)$ heifer BCS change over time (Figure $2)$. The quadratic coefficient was significant $(P=0.02)$ for the MPR treatment but only tended $(P=0.12)$ to be significant for the CPR treatment. The CPR heifers lost more BCS in the fall and less during the winter than MPR heifers, which caused the quadratic coefficient to approach non-significance. Heifers on both treatments lost substantial condition from December to February.

In Exp. 2, heifer BW varied $(P=0.0001)$ over time (Figure 3). The MPR/no hay heifers had a lower BW than the MPR/hay $(P=0.03)$ and $\mathrm{CPR} /$ hay $(P=0.01)$ heifers (mean $\mathrm{BW}=410,414,390 \mathrm{~kg}[\mathrm{SEM}=6 \mathrm{~kg}$ for MPR/hay, CPR/hay and MPR/no hay, respectively]). Quadratic equations did not strongly describe $(P=0.15)$ heifer BW loss over time. A time linear $\times$ treatment interaction $(P=0.02)$ occurred for BW. The BW of MPR/ no hay heifers declined linearly $(P=0.0001)$ over time, whereas MPR/hay and CPR/hay heifers were able to maintain BW $(P=0.50)$. Ruminal DM fill likely caused a portion of the BW difference between hay fed heifers and heifers not fed hay. Heifer BCS (Figure 4) varied $(P=0.0001)$ over time and tended to vary $(P=0.11)$ across treatments. The MPR/no hay treatment had a lower BCS $(P=0.04)$ than the MPR/hay treatment ( mean BCS $=5.6$ vs $5.8[\mathrm{SEM}=0.07]$ for $\mathrm{MPR} /$ no hay and MPR/hay, respectively), but the MPR/hay treat-

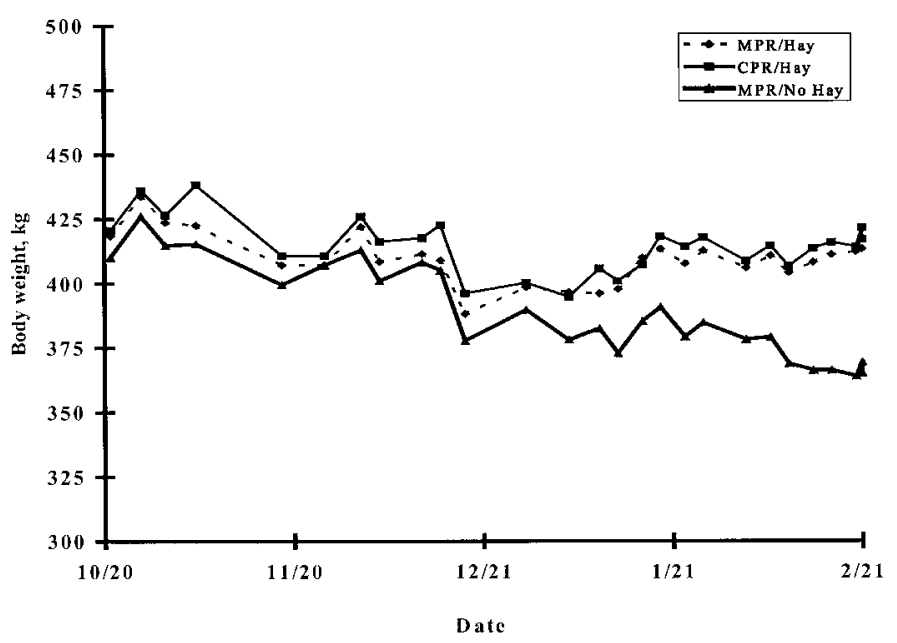

Figure 3. Body weight of heifers grazing native range over the winter of 1998 to 1999 (Exp. 2) when supplemented to meet metabolizable protein or $\mathrm{CP}$ requirements and fed hay in January and February (MPR/hay and $\mathrm{CPR} /$ hay, respectively), or supplemented to meet metabolizable protein requirements and not fed hay (MPR/ no hay).

ment did not differ $(P=0.30)$ from the CPR/hay treatment (mean BCS $=5.7)$. Quadratic terms did not fit $(P$ $=0.85)$ the change in heifer BCS over time. A time linear $\times$ treatment interaction occurred for BCS $(P=$ 0.01 ), representing the loss of BCS by the MPR/no hay treatment in January and February.

The nutrient balance of the heifers during Exp. 1 and 2 are shown in Tables 7 and 8, respectively. Degradable intake protein was adequate in all diets during both experiments. However, energy $\left(\mathrm{NE}_{\mathrm{m}}\right)$ and $\mathrm{MP}$ were not

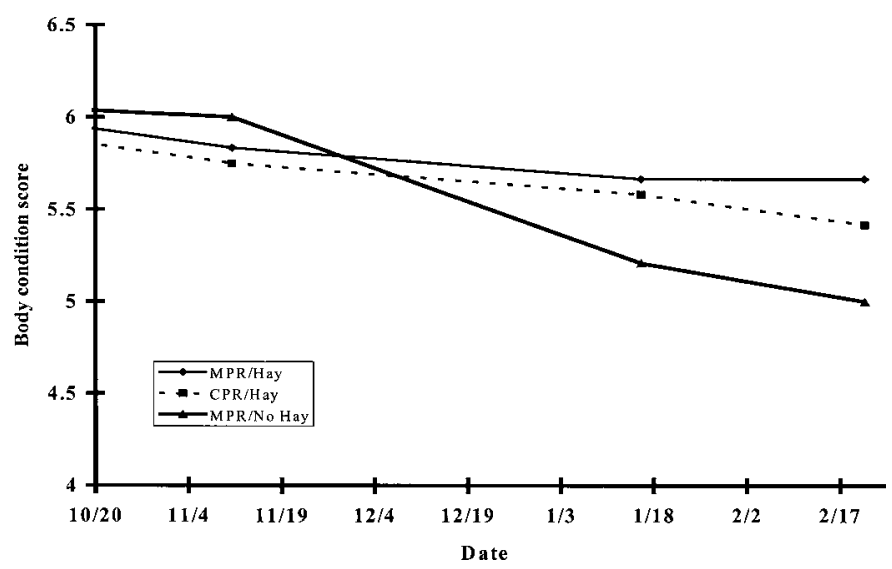

Figure 4. Body condition score ( 1 to 9 scale; $1=$ emaciated, $9=$ obese) of heifers grazing native range over the winter of 1998 to 1999 (Exp. 2) when supplemented to meet metabolizable protein or $\mathrm{CP}$ requirements and fed hay in January and February (MPR/hay and CPR/hay, respectively), or supplemented to meet metabolizable protein requirements and not fed hay (MPR/no hay). 
Table 7. Nutrient balance of heifers supplemented to meet metabolizable protein requirements (MPR) or CP requirements (CPR) in 1997 to 1998 (Exp. 1) ${ }^{\mathrm{a}}$

\begin{tabular}{|c|c|c|c|c|c|c|}
\hline \multirow[b]{2}{*}{ Item } & \multicolumn{2}{|c|}{ November } & \multicolumn{2}{|c|}{ January } & \multicolumn{2}{|c|}{ February } \\
\hline & MPR & $\mathrm{CPR}$ & MPR & CPR & MPR & CPR \\
\hline DMI, kg ${ }^{\mathrm{b}}$ & 10.5 & 9.1 & 7.5 & 7.1 & 6.4 & 6.1 \\
\hline $\mathrm{NE}_{\mathrm{m}}$ balance, Mcal & 2.3 & 0.9 & -2.9 & -3.2 & -5.4 & -5.5 \\
\hline MP supplied, $\mathrm{g}^{\mathrm{c}}$ & 531 & 417 & 394 & 323 & 376 & 298 \\
\hline $\mathrm{MP}$ required, $\mathrm{g}^{\mathrm{c}}$ & 484 & 436 & 461 & 456 & 540 & 527 \\
\hline MP balance, $\mathrm{g}^{\mathrm{c}}$ & 46 & -19 & -67 & -133 & -163 & -229 \\
\hline DIP supplied, $\mathrm{g}^{\mathrm{d}}$ & 527 & 508 & 401 & 425 & 328 & 367 \\
\hline DIP required, $\mathrm{g}^{\mathrm{d}}$ & 529 & 457 & 360 & 341 & 314 & 298 \\
\hline DIP balance, $\mathrm{g}^{\mathrm{d}}$ & -2 & 50 & 41 & 84 & 34 & 69 \\
\hline
\end{tabular}

${ }^{\mathrm{a}}$ Calculated using NRC (1996) model.

${ }^{\mathrm{b}}$ Total intake.

${ }^{\mathrm{c}} \mathrm{MP}=$ metabolizable protein .

${ }^{\mathrm{d}} \mathrm{DIP}=$ degradable intake protein.

adequate in all situations. Metabolizable protein was deficient $(-19 \mathrm{~g})$ to the CPR heifers in November of Exp. 1 , but was positive ( $+46 \mathrm{~g}$ ) for MPR heifers. The energy and protein balance of the MPR heifers during November explains the increased BW gain observed for that treatment during the fall and the noted treatment $x$ time interaction for BW and BCS. It seems that the MPR supplement was formulated correctly to meet the MP requirements of the heifers in the fall. Energy and MP were deficient in both groups of heifers in January and February of Exp. 1, explaining the decline in BW and body condition. Low energy intakes, combined with increased animal requirements, caused a $\mathrm{NE}_{\mathrm{m}}$ deficiency, reaching -5.5 Mcal/d in February. The low energy intakes reduced MP balance in January and February as well, and the MPR supplement did not supply enough UIP to meet the MP requirement. The MPR heifers were less deficient in MP than CPR heifers in February of Exp. 1.

The MPR heifers were adequate in MP in December of Exp. 2 (Table 8), whereas CPR heifers were $26 \mathrm{~g}$ deficient. Energy intake was slightly deficient in December for all heifers. Dry matter intakes (forage + supplement) in December of Exp. 2 were similar to those measured in January of Exp. 1. Energy balances in December of Exp. 2 were intermediate to the energy balances estimated in November and January of Exp. 1. The MPR/hay heifers were slightly deficient in MP in February, whereas the other treatment groups were more negative. However, energy was deficient in all treatments. Feeding hay helped reduce the energy deficiency in February noted in heifers not fed hay, explaining the better performance by heifers fed hay.

The reason that heifers on the MPR treatment tended to gain more in the fall in Exp. 1 (treatment $\times$ time interaction, $P=0.11$ ) but not Exp. 2 is not evident. Supplemental feeding began $9 \mathrm{~d}$ earlier in Exp. 1. Heifers may have responded more to balanced MP in the diet when energy was not limiting in mid-October; however, a 9-d difference in initial feeding date would not be expected to result in the $20-\mathrm{kg}$ difference $(P=0.02)$ in BW measured during the February intake period of

Table 8. Nutrient balance of heifers in 1998 to 1999 (Exp. 2) supplemented to meet metabolizable protein or $\mathrm{CP}$ requirements with hay feeding in January and February

(MPR/hay and CPR/hay, respectively) or supplemented to meet metabolizable protein requirements and not fed hay (MPR/no hay) ${ }^{\mathrm{a}}$

\begin{tabular}{|c|c|c|c|c|c|c|}
\hline \multirow[b]{2}{*}{ Item } & \multicolumn{3}{|c|}{ December } & \multicolumn{3}{|c|}{ February } \\
\hline & MPR/hay & CPR/hay & MPR/no hay & MPR/hay & CPR/hay & MPR/no hay \\
\hline $\mathrm{DM}$ intake, $\mathrm{kg}^{\mathrm{b}}$ & 7.1 & 7.7 & 8.5 & 8.0 & 8.2 & 6.0 \\
\hline $\mathrm{NE}_{\mathrm{m}}$ balance, Mcal & -1.2 & -0.9 & 0.3 & -3.0 & -3.3 & -5.1 \\
\hline MP supplied, $\mathrm{g}^{\mathrm{c}}$ & 408 & 374 & 465 & 512 & 400 & 415 \\
\hline MP required, $\mathrm{g}^{\mathrm{c}}$ & 395 & 400 & 404 & 523 & 525 & 497 \\
\hline MP balance, $\mathrm{g}^{\mathrm{c}}$ & 13 & -26 & 61 & -11 & -125 & -82 \\
\hline DIP supplied, $\mathrm{g}^{\mathrm{d}}$ & 426 & 489 & 488 & 534 & 523 & 389 \\
\hline DIP required, $\mathrm{g}^{\mathrm{d}}$ & 358 & 381 & 423 & 402 & 401 & 288 \\
\hline DIP balance, $\mathrm{g}^{\mathrm{d}}$ & 68 & 108 & 66 & 132 & 122 & 101 \\
\hline
\end{tabular}

${ }^{\mathrm{a} C a l c u l a t e d}$ using NRC (1996) model.

${ }^{\mathrm{b}}$ Total intake.

${ }^{\mathrm{c}} \mathrm{MP}=$ metabolizable protein.

${ }^{\mathrm{d}} \mathrm{DIP}=$ degradable intake protein. 
Table 9. Performance by 2-yr-old lactating cows (Exp. 3) consuming meadow hay and supplemented to meet metabolizable protein requirements (LMPR) or degradable intake protein requirements (LDIPR) ${ }^{\mathrm{a}}$

\begin{tabular}{lccc}
\hline \hline Item & LMPR $^{\mathrm{b}}$ & LDIPR $^{\mathrm{b}}$ & SEM \\
\hline Calving date & March 23 & March 22 & - \\
Cow initial BW, kg & 377 & 382 & 9 \\
Cow final BW, kg & 397 & 390 & 7 \\
Cow ADG, kg & 0.41 & 0.14 & 0.07 \\
Cow initial BCS & 4.6 & 4.8 & 0.1 \\
Cow final BCS & 4.8 & 4.7 & 0.1 \\
Average daily BCS change & 0.004 & -0.001 & 0.003 \\
Calf initial BW, kg & 47 & 46 & 2 \\
Calf final BW, kg & 77 & 75 & 2 \\
Calf ADG, kg & 0.62 & 0.59 & 0.03 \\
\hline
\end{tabular}

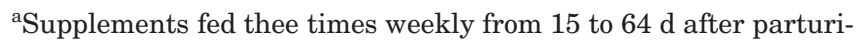
tion. Meadow hay was $9.5 \% \mathrm{CP}, 80 \% \mathrm{NDF}$ (OM basis).

${ }^{\mathrm{b}} \mathrm{n}=9$.

cTreatments differ, $P=0.02$.

Exp. 1. Spring-calving cows grazing Sandhills range in the winter have been shown to have a requirement for DIP (Hollingsworth-Jenkins et al., 1996) but not UIP (Karges, 1990). In contrast, Miner et al. (1990) found that the addition of either blood meal or corn gluten meal to soybean meal supplements for gestating beef cows during the winter decreased BCS loss compared to no supplement or soybean meal supplementation. In a companion study to the current experiments, Patterson et al. (2000a) showed that balancing the MP requirements of gestating heifers improved subsequent pregnancy rate without affecting BW or BCS change during the winter. The data reported in this study show that MP deficiencies might be reduced when sources of UIP are supplemented during winter, and there is the potential for UIP supplementation to improve performance if energy intake is not limiting.

\section{Experiment 3}

The average calving date was similar for the LMPR and LDIPR treatments (Table 9; March 23 and March 22 , respectively). Cows on the LMPR treatment had a higher ADG $(P=0.02)$ than cows on the LDIPR treatment ( $0.41 \mathrm{vs} 0.14 \mathrm{~kg} / \mathrm{d}$ for LMPR and LDIPR, respectively). There were no differences in cow BCS change $(P=0.21)$, but cows on the LMPR had a positive BCS change compared to the negative change observed with the LDIPR treatment. Calf gain was not affected by treatment.

Cow BW at the start of the fecal collection period (May 3), which were estimated from initial weight and ADG for each animal, were the same between treatments (Table 10; $387 \pm 8 \mathrm{~kg}$ ). Due to regurgitation of the time-release capsules, only six and eight heifers were in the intake analysis for LMPR and LDIPR treatments, respectively. There were no effects $(P=0.53)$ of treatment on fecal OM output or OM hay intake. Hay $\mathrm{OM}$ intake averaged $9.2 \mathrm{~kg}$ and $2.4 \%$ of BW.

Twenty-four-hour milk production did not differ $(P=$ $0.97)$ between treatments in April or May (Table 11). Milk production declined ( $P=0.0005)$ from an average $7.2 \mathrm{~kg} / \mathrm{d}$ in April to $4.9 \mathrm{~kg} / \mathrm{d}$ in May across both treatments. Peak milk production occurred sooner than the value of 8.5 wk predicted by NRC (1996). Supplementation with UIP during the postpartum period has been shown to increase milk production (Kaur and Arora, 1995). Blasi et al. (1991) showed that $230 \mathrm{~g} / \mathrm{d}$ of UIP supplemented to lactating cows increased milk production, but $340 \mathrm{~g} / \mathrm{d}$ of UIP decreased milk production. Appeddu et al. (1996) hypothesized that UIP supplementation repartitioned nutrients away from milk and towards body condition.

The nutrient balance of both treatments in April and May is shown in Table 11. Cows on the LDIPR treatment did not consume all of the supplement offered. On average, the LDIPR cows consumed 454 of the 590 $\mathrm{g}$ of supplement offered per day, with a range of 383 to $481 \mathrm{~g} / \mathrm{d}$ across all cows in that treatment. Few refusals were recorded for the LMPR treatment. Despite the low supplement consumption on the LDIPR treatment, DIP was in excess for both treatments in April and May. Energy was markedly deficient for both treatments in April and slightly deficient in May. Metabolizable protein was deficient for both groups in April ( -68 and $-181 \mathrm{~g} / \mathrm{d}$ for LMPR and LDIPR, respectively). The reason that the LMPR did not meet MP requirements in April is that milk production was underpredicted for the cows when supplements were formulated. In May, when milk production declined, the LMPR cows were $+58 \mathrm{~g} / \mathrm{d}$ in MP compared with $-57 \mathrm{~g} / \mathrm{d}$ for the LDIPR cows. Reducing the MP deficiency in April and alleviating the deficiency in May resulted in the higher ADG by the LMPR cows. Plasma progesterone was not above $1 \mathrm{ng} / \mathrm{mL}$ for any cow at any sampling point, indicating that no cows exhibited luteal activity by May 17 (second to last bleeding).

Table 10. Organic matter fecal output and intake by 2yr-old lactating cows (Exp. 3) consuming meadow hay and supplemented to meet metabolizable protein requirements (LMPR) or degradable intake protein requirements (LDIPR) ${ }^{\mathrm{a}}$

\begin{tabular}{lcc}
\hline \hline Item & LMPR $^{\mathrm{b}}$ & LDIPR $^{\mathrm{c}}$ \\
\hline BW, kgd & $387 \pm 8$ & $387 \pm 8$ \\
Fecal output, kg & $4.0 \pm 0.4$ & $4.3 \pm 0.3$ \\
Fecal output, \% of BW & $1.06 \pm 0.11$ & $1.12 \pm 0.08$ \\
Hay intake, kg & $8.8 \pm 0.8$ & $9.5 \pm 0.7$ \\
Hay intake, \% of BW & $2.3 \pm 0.2$ & $2.5 \pm 0.2$ \\
\hline
\end{tabular}

asupplements fed thee times weekly from 15 to $64 \mathrm{~d}$ after parturition. Meadow hay was $9.5 \% \mathrm{CP}, 80 \% \mathrm{NDF}$ (OM basis).

${ }^{\mathrm{b}} \mathrm{n}=6$.

${ }^{\mathrm{c}} \mathrm{n}=8$.

${ }^{\mathrm{d} B o d y}$ weight at start of intake measurement (May 3, 1999) was estimated by initial $\mathrm{BW}$ and $\mathrm{ADG}$. 
Table 11. Milk production and estimated nutrient balance of lactating 2-yr-old cows

(Exp. 3) consuming meadow hay and supplemented to meet metabolizable protein (LMPR) or degradable intake protein (LDIPR) requirements ${ }^{\mathrm{ab}}$

\begin{tabular}{|c|c|c|c|c|}
\hline \multirow[b]{2}{*}{ Item } & \multicolumn{2}{|c|}{ April 21, 1999} & \multicolumn{2}{|c|}{ May 18, 1999} \\
\hline & LMPR & LDIPR & LMPR & LDIPR \\
\hline Milk production, $\mathrm{kg} / \mathrm{d}^{\mathrm{c}}$ & 7.2 & 7.3 & 4.9 & 4.8 \\
\hline DM intake, $\mathrm{kg}^{\mathrm{d}}$ & 10.5 & 10.8 & 10.5 & 10.8 \\
\hline $\mathrm{NE}_{\mathrm{m}}$ balance, Mcal & -2.4 & -2.2 & -0.6 & -0.4 \\
\hline MP supplied, ge & 643 & 531 & 643 & 531 \\
\hline MP required, $\mathrm{g}^{\mathrm{e}}$ & 710 & 712 & 585 & 587 \\
\hline MP balance, $\mathrm{g}^{\mathrm{e}}$ & -66 & -181 & 58 & -57 \\
\hline DIP supplied, $\mathrm{g}^{\mathrm{f}}$ & 858 & 863 & 858 & 869 \\
\hline DIP required, $g^{f}$ & 592 & 608 & 592 & 608 \\
\hline DIP balance, $\mathrm{g}^{\mathrm{f}}$ & 266 & 255 & 266 & 255 \\
\hline Days to lose one BCS & 54 & 60 & 197 & 292 \\
\hline
\end{tabular}

${ }^{\mathrm{a} C a l c u l a t e d}$ using NRC (1996) model.

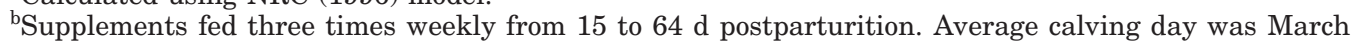
23,1999 . Meadow hay was $9.5 \% \mathrm{CP}, 80 \% \mathrm{NDF}$ (OM basis).

'Twenty-four-hour milk production was determined by the weigh-suckle-weigh procedure; $\mathrm{SEM}=0.6$; milk production declined $(P=0.0005)$ across measurement dates.

${ }^{\mathrm{d}}$ Total intake; hay intake was determined using a marker on May 3 to 8, 1999.

${ }^{\mathrm{e}} \mathrm{MP}=$ metabolizable protein .

${ }^{\mathrm{f}} \mathrm{DIP}=$ degradable intake protein.

Similar to our results, Wiley et al. (1991) showed that UIP supplementation to lactating cows increased postpartum BW change. These authors reported that UIP supplementation also increased the percentage of cows bred in the first $21 \mathrm{~d}$ of the breeding season. Breeding performance was not measured in the current study, but no differences were noted in luteal activity within $60 \mathrm{~d}$ after calving. Young cows often have longer postpartum intervals (PPI) than mature cows (Short et al., 1990). Lalman et al. (2000) reported PPI of greater than $100 \mathrm{~d}$ for primiparous beef cows, regardless of postpartum energy level, but low postpartum energy intake increased PPI compared to high postpartum energy intake. Both precalving energy level (Bellows and Short, 1978) and BCS at calving (Richards et al., 1986) can affect PPI. The cows in the current study were at a BCS of 4.7 at the initiation of the experiment, which was a marginal level of condition for young, lactating cows (Richards et al., 1986). Lardy et al. (1999), working with summer-calving cows, found no response to UIP supplementation (in addition to DIP) on cow BW loss or pregnancy rate. The results of the current study showed that UIP supplementation to spring-calving, 2yr-old cows consuming meadow hay increased postpartum BW change.

\section{Implications}

Pregnant heifers grazing winter range and lactating 2-yr-old cows consuming meadow hay are deficient in metabolizable protein. Supplementing heifers to meet metabolizable protein requirements in gestation may not result in marked differences in body weight and body condition score. Grazed forage intake of pregnant heifers decreases with advancing gestation, necessitating the need for supplemental energy.

\section{Literature Cited}

Adams, D. C., T. C. Nelson, W. L. Reynolds, and B. W. Knapp. 1986. Winter grazing activity and forage intake of range cows in the Northern Great Plains. J. Anim. Sci. 62:1240-1246.

Adams, D. C., and R. E. Short. 1988. The role of animal nutrition on productivity in a range environment. Pages $37-43$ in Achieving Efficient Use of Rangeland Resources. R. S. White and R. E. Short, ed. Montana Agric. Exp. Stn., Bozeman.

Adams, D. C., R. E. Short, M. M. Borman, and M. D. McNeil. 1991. Estimation of fecal output with an intraruminal continuous release marker device. J. Range Manage. 44:204-207.

Adams, D. C., R. E. Short, and B. W. Knapp. 1987. Body size and body condition effects on performance and behavior of grazing beef cows. Nutr. Rep. Int. 35:269-277.

Allison, C. D. 1985. Factors affecting forage intake by range ruminants: A review. J. Range Manage. 38:305-311.

Allison, C. D., M. M. Kothmann, and L. R. Rittenhouse. 1981. Forage intake of cattle as affected by grazing pressure. Pages 670-672 in Proc. XIV Int. Grasslands Cong. J. A. Smith and V. W. Hays, ed. Westview Press, Boulder, CO.

AOAC. 1990. Official Methods of Analysis. 14th ed. Assoc. Offic. Anal. Chem. Arlington, VA.

Appeddu, L. A., M. K. Petersen, J. S. Serrato-Corona, L. F. Gulino, I. Tovar-Luna, G. B. Donart, D. E. Hawkins, J. R. Strickland, E. E. Parker, and S. Cox. 1996. Postpartum reproductive responses of two year old range cows supplemented with protein, fat, or energy. Proc. West. Sec. Amer. Soc. Anim. Sci. 47:2-6.

Bellows, R. A., and R. E. Short. 1978. Effects of precalving feed level on birth weight, calving difficulty and subsequent fertility. J. Anim. Sci. 46:1522-1528.

Blasi, D. A., J. K. Ward, T. J. Klopfenstein, and R. A. Britton. 1991. Escape protein for beef cows: III. Performance of lactating beef cows grazing smooth brome or big bluestem. J. Anim. Sci. 69:2294-2302.

Christopherson, R. J. 1976. Effects of prolonged cold and outdoor winter environment on apparent digestibility in sheep and cattle. Can. J. Anim. Sci. 56:201-212.

Downs, D. 1997. Diet composition of sandhills winter range and compensatory growth of yearling steers during summer grazing. M.S. Thesis, Univ. of Nebraska, Lincoln.

Faichney, G. J., and G. A. White. 1988. Rates of passage of solutes, microbes and particulate matter through the gastrointestinal 
tract of ewes fed at a constant rate throughout gestation. Aust. J. Agric. Res. 39:481-492.

Forbes, J. M. 1969. The effect of pregnancy and fatness on the volume of rumen contents in the ewe. J. Agric. Sci. 72:119-121.

Forbes, J. M. 1970. Voluntary food intake of pregnant ewes. J. Anim. Sci. 31:1222-1227.

Grummer, R. R., P. C. Hoffman, M. L. Luck, and S. J. Bertics. 1995. Effect of prepartum and postpartum dietary energy on growth and lactation of primiparous cows. J. Dairy Sci. 78:172-180.

Handl, W. P., and L. R. Rittenhouse. 1972. Herbage yield and intake of steers. Proc. West. Sec. Am. Soc. Anim. Sci. 23:197-200.

Hollingsworth-Jenkins, K. J., T. J. Klopfenstein, D. C. Adams, and J. B. Lamb. 1996. Ruminally degradable protein requirement of gestating beef cows grazing native winter sandhills range. J. Anim. Sci. 74:1343-1348.

Jordan, W. A., E. E. Lister, J. M. Wauthy, and J. E. Comeau. 1973. Voluntary roughage intake by nonpregnant and pregnant or lactating beef cows. Can. J. Anim. Sci. 53:733-738.

Karges, K. K. 1990. Effects of rumen degradable and escape protein on cattle response to supplemental protein on native range. $\mathrm{M}$. S. Thesis, Univ. of Nebraska, Lincoln.

Kartchner, R. J. 1981. Effects of protein and energy supplementation of cows grazing native winter range forage on intake and digestibility. J. Anim. Sci. 51:432-438.

Kaur, H., and S. P. Arora. 1995. Dietary effects on ruminant livestock reproduction with particular reference to protein. Nutr. Res. Rev. 8:121-136.

Klopfenstein, T., R. Mass, K. Creighton, and T. Patterson. 2000. Estimating forage protein degradation in the rumen. J. Anim. Sci. 78(Suppl. 1):15. (Abstr.)

Lalman, D. L., J. E. Williams, B. W. Hess, M. G. Thomas, and D. H. Keisler. 2000. Effect of dietary energy on milk production and metabolic hormones in thin, primiparous beef heifers. J. Anim. Sci. 78:530-538.

Lamb, J. 1996. Plant maturity effects on intake, digestibility, and rumen kinetics of leaf and stem fractions of Sandhills grasses in beef steers. Ph.D. Diss., Univ. of Nebraska, Lincoln.

Lardy, G. P. 1997. Protein supplementation of calves and cows grazing sandhills range and subirrigated meadow. Ph.D. Diss., Univ. of Nebraska, Lincoln.

Lardy, G. P., D. C. Adams, T. J. Klopfenstein, and R. T. Clark. 1999. First limiting nutrient for summer calving cows grazing autumnwinter range. J. Range Manage. 52:317-326.

Littell, R. C., G. A. Milliken, W. W. Stroup, and R. D. Wolfinger. 1996. SAS System for Mixed Models. SAS Inst., Inc., Cary, NC.

Mass, R. A., G. P. Lardy, R. J. Grant, and T. J. Klopfenstein. 1999. In situ neutral detergent insoluble nitrogen as a method for measuring forage protein degradability. J. Anim. Sci. 77:1565-1571.

Melvin, E. J., B. R. Lindsey, J. Quintal-Franco, E. Zanella, K. E. Fike, C. P. Van Tassell, and J. E. Kinder. 1999. Circulating concentrations of estradiol, luteinizing hormone, and folliclestimulating hormone during waves of ovarian follicular development in prepubertal cattle. Biology of Reprod. 60:405-412.

Mertens, D. R. 1994. Regulation of forage intake. Pages 450-493 in Forage Quality, Evaluation, and Utilization. G. C. Fahey Jr., M. Collins, D. R. Mertens, and L. E. Moser, ed. Am. Soc. of Agron., Crop Sci. Soc. of Am., Soil Science Soc. of Am., Madison, WI.

Miner, J. L., M. K. Petersen, K. M. Havstad, M. J. McInernery, and R. A. Bellows. 1990. The effects of ruminal escape protein or fat on nutritional status of pregnant winter-grazing beef cows. J. Anim. Sci. 68:1743-1750.

NRC. 1996. Nutrient requirements of beef cattle. 7th ed. Natl. Acad. Press, Washington, DC.

Patterson, H. H. 2000. Protein supplementation to pregnant heifers and grazing management effects on cow diet quality. Ph.D. Diss., Univ. of Nebraska, Lincoln.

Patterson, H. H., D. C. Adams, T. J. Klopfenstein, and B. Teichert. 2000a. Winter supplementation of primiparous heifers grazing winter range based on the Metabolizable Protein System versus the Crude Protein System. Proc. West. Sec. Amer. Soc. Anim. Sci. 51:61-64.

Patterson, H. H., T. J. Klopfenstein, D. C. Adams, W. H. Schacht, P. E. Reece, and A. E. Herron. 2000b. Summer grazing and fall grazing pressure effects on protein content and digestibility of fall range diets in the Nebraska Sandhills. Proc. West. Sec. Amer. Soc. Anim. Sci. 51:316-319.

Pinchak, W. E., S. K. Canon, R. K. Heitshmidt, and S. L. Dowher. 1990. Effect of long-term, year-long grazing at moderate and heavy rates of stocking on diet selection and forage intake dynamics. J. Range Manage. 43:304-309.

Ramsey, W. S., P. G. Hatfield, and J. D. Wallace. 1998. Relationships among ewe milk production and ewe and lamb forage intake in Suffolk and Targhee ewes nursing single or twin lambs. J. Anim. Sci. 75:1247-1253.

Richards, M. W., J. C. Spitzer, and M. B. Warner. 1986. Effect of varying levels of postpartum nutrition and body condition at calving on subsequent reproductive performance in beef cattle. J. Anim. Sci. 62:300-306.

Short, R. E., R. A. Bellows, R. B. Staigmiller, J. G. Berardinelli, and E. E. Custer. 1990. Physiological mechanisms controlling anestrus and infertility in postpartum beef cattle. J. Anim. Sci. 68:799-816.

Stanley, T. A., R. C. Cochran, E. S. Vanzant, D. L. Harmon, and L. R. Corah. 1993. Periparturient changes in intake, ruminal capacity, and digestive characteristics in beef cows consuming alfalfa hay. J. Anim. Sci. 71:788-795.

Tilley, J. M. A., and R. A. Terry. 1963. A two-stage technique for the in vitro digestion of forages. J. Br. Grassl. Soc. 18:104-111.

Vanzant, E. S., R. C. Cochran, and D. E. Johnson. 1991. Pregnancy and lactation in beef heifers grazing tallgrass prairie in winter: Influence on intake, forage utilization, and grazing behavior. J. Anim. Sci. 69:3027-3038.

Vavra, M., R. W. Rice, and R. E. Bement. 1973. Chemical composition of the diet, intake, and gain of yearling cattle on different grazing intensities. J. Anim. Sci. 36:411-414.

Weiss, W. P. 1994. Estimation of digestibility of forages by laboratory methods. Pages 644-681 in Forage Quality, Evaluation, and Utilization. G. C. Fahey Jr., M. Collins, D. R. Mertens, and L. E. Moser, ed. Am. Soc. of Agron., Crop Sci. Soc. of Am., Soil Sci. Soc. of Am., Madison, WI.

Wiley, J. S., M. K. Petersen, R. P. Ansotegui, and R. A. Bellows. 1991. Production from first-calf beef heifers fed a maintenance or low level of prepartum nutrition and ruminally undegradable or degradable protein postpartum. J. Anim. Sci. 69:4279-4293.

Williams, C. H., D. J. David, and O. Iismaa. 1962. The determination of chromic oxide in feces samples by atomic absorption spectrophotometry. J. Agric. Sci. (Camb.). 59:381-385.

Yates, D. A., D. C. Clanton, and J. T. Nichols. 1982. Effect of continuous grazing on the diet of steers. J. Range Manage. 35:339-341. 